Славяноведение 2013-2023

ISSN 2079-8784

URL - $\underline{\text { http: }: / / \text { ras.jes.su }}$

Все права защищены

Номер 6 Том . 2018

\title{
D. Paśko-Koneczniak. Słownik zapożyczeń polskich w rosyjskiej gwarze staroobrzędowców z regionu suwalsko- augustowskiego
}

Ганенкова T. C.

Российская Федерацчия

Аннотация

Ключевые слова:

Дата публикации: 20.12.2018

Источник финансирования:

Статья написана при поддержке гранта РНФ 16-18-02080 «Русский язык как основа сохранения идентичности старообрядцев Центральной и Юго-Восточной Европы».

Ссылка для цитирования:

Ганенкова T. C. D. Paśko-Koneczniak. Słownik zapożyczeń polskich w rosyjskiej gwarze staroobrzędowców z regionu suwalsko-augustowskiego // Славяноведение 2018. - Номер 6 C. 120-126 [Электронный ресурс]. URL:

https://slav.jes.su/S0869544X0001771-1-1 (дата обращения: 26.04.2023). DOI: 10.31857/S0869544X0001771-1 
1. Pasko-Koneczniak D. Slownik zapozyczen polskich w rosyjskiej gwarze staroobrzedowcow z regionu suwalskoaugustowskiego. Torun, 2016.

2. Pasko-Koneczniak D. Wplyw polszczyzny na zasob leksykalny rosyjskiej gwary staroobrzedowco?w na Suwalszczyznie. orun, 2011.

3. Iwaniec E. Z dziejow staroobrzedowco?w na ziemiach polskich XVII-XX w. Warszawa, 1977.

4. Grek-Pabisowa I. Staroobrzedowcy. Szkice z historii, jezyka, obyczajo?w. Warszawa, 1999.

5. Grek-Pabisowa I. Rosyjska gwara starowierco?w w wojewo?dztwach olsztynskim i bialostockim. Wroclaw; Warszawa; Krako?w; Gdansk, 1968.

6. Морозова Н., Чекмонас В. Говоры старообрядцев Литвы: особенности и проблемы происхождения // Фольклор старообрядцев Литвы: тексты и исследования. Вильнюс, 2007. Т. І.

7. Grek-Pabisowa I., Maryniakowa I. Slownik gwary starowierco?w mieszkajacych w Polsce. Wroclaw; Warszawa; Krako?w, 1980.

8. Ганенкова Т.С. Полевое исследование старообрядцев в Польше // Славяноведение. 2018. № 2.

9. Pasko-Koneczniak D. Koncepcja «Slownika zapozyczen polskich w rosyjskiej gwarze staroobrzedowco?w z regionu suwalsko-augustowskiego» // Slowianskie slowniki gwarowe - tradycja i nowa-torstwo / Red. D.K. Rembiszewska. Warszawa; Lomza, 2016.

10. Псковский областной словарь с историческими данными. Ленинград/СПб., 1967. T. 1.

11. Псковский областной словарь с историческими данными. Ленинград/СПб, 2012. T. 23.

12. Словарь русских народных говоров. Ленинград/СПб., 1987. Т. 23.

13. Даль В.И. Толковый словарь живого великорусского языка. М., 1880. Т. 2.

14. Псковский областной словарь с историческими данными. Ленинград/СПб., 2004. T. 16.

15. Словарь русских народных говоров. Ленинград/СПб., 1979. Т. 15.

16. Даль В.И. Толковый словарь живого великорусского языка. М., 1882. Т. 4.

17. Словарь русских народных говоров. Ленинград/СПб., 2002. Т. 36.

18. Псковский областной словарь с историческими данными. СПб., 1983. Т. 5. 
19. Псковский областной словарь с историческими данными. Ленинград/ СПб., 1984. T. 6.

20. Фасмер М. Этимологический словарь русского языка. М., 1987. Т. 3.

21. Фасмер М. Этимологический словарь русского языка. М., 1986. Т. 2.

22. Гжибовский Ст., Глушковский М. Социолингвистическая ситуация старообрядцев в деревнях Габове Гронды и Бур // Русские старообрядцы: язык, культура, история. Сб. статей к XIV Международному съезду славистов / Отв. ред. Л.Л. Касаткин. М., 2008. 


\section{T. Ganenkova}

Russian Federation

Abstract

Keywords:

Publication date: 20.12 .2018

\section{Citation link:}

Ganenkova T. // Slavianovedenie - 2018. - Issue 6 C. 120-126 [Electronic resource]. URL: https://slav.jes.su/S0869544X0001771-1-1 (circulation date: 26.04.2023). DOI: 10.31857/S0869544X0001771-1

Код пользователя: 0; Дата выгрузки: 26.04.2023; URL - http://ras.jes.su/slav/s207987840001005-4-1 Bce права защищены. 